\title{
Faktor Penentu Minat Beli Produk Makanan dan Minuman Impor Berlabel Halal
}

\author{
Gilang Pandega Mulasakti ${ }^{1}$, Fuad Mas'ud $^{2}$ \\ ${ }^{1,2}$ Program Studi Ekonomi Islam, Fakultas Ekonomika dan Bisnis, Universitas Diponegoro \\ *E-mail Korespondensi: pandegagilang@gmail.com
}

\begin{abstract}
As a country, Indonesia is inseparable from import activities to meet their own needs. Indonesia is a country with the largest Muslim population in the world. Muslims are required to always consume halal food in accordance with Islamic religious orders. However, in fact, not all imported food or beverage products are labeled as halal food. This study aims to analyze the effect of product quality, attitudes, subjective norms, perceived behavioral control and religiosity on the buying interest of Universitas Diponegoro students on imported halal labeled food and beverages. The data collection method is done through questionnaire. The population of this research is Muslim students at Universitas Diponegoro who consume imported food and beverages with sample of 110 respondents. This study uses multiple linear regression analysis techniques that are calculated using the SPSS 26.0 application. The results of the analysis showed that the product quality, attitude, perceived behavioral control and religiosity had a positive and significant effect on the buying interest of Universitas Diponegoro students on imported food and beverage labeled as halal. However, subjective norm are not significant to the buying interest of Universitas Diponegoro students on imported food and beverages labeled halal.
\end{abstract}

Keywords : product quality, theory of planned behavior, religiosity

Saran sitasi: Mulasakti, G. P., \& Mas'ud, F. (2020). Faktor Penentu Minat Beli Produk Makanan dan Minuman Impor Berlabel Halal. Jurnal Ilmiah Ekonomi Islam, 6(02),294-303. doi:http://dx.doi.org/10.29040/jiei.v6i2.796

DOI: http://dx.doi.org/10.29040/jiei.v6i2.796

\section{PENDAHULUAN}

Indonesia merupakan negara dengan populasi terbesar keempat di dunia. Berdasarkan data sensus 2010 yang dihimpun oleh Badan Pusat Statistik (BPS), populasi indonesia mencapai lebih dari 237 juta jiwa. Berdasarkan laporan BPS pada sensus 2010 (Badan Pusat Statistik, 2010), 87,16\% dari seluruh populasi penduduk Indonesia atau 207 juta lebih jiwa merupakan umat Islam.

Melihat besarnya populasi Indonesia, sangat rasional bagi merk global untuk menjadikan pasar Indonesia sebagai salah satu sasaran untuk memasarkan produknya. Menurut data Kementerian Perdagangan RI, tren impor untuk sektor makanan dan minuman untuk rumah tangga tahun 2014-2018 terus mengalami peningkatan dengan sedikit penurunan pada tahun 2015. Pada tahun 2018, Indonesia mengimpor makanan dan minuman yang sudah maupun belum diolah dengan nilai total $6.456,3$ juta dolar AS.

Tabel 1 Impor Makanan dan Minuman untuk Rumah Tangga (Juta Dolar AS)

\begin{tabular}{ccc}
\hline \multirow{2}{*}{ Tahun } & \multicolumn{2}{c}{ Makanan dan Minuman untuk Rumah } \\
& \multicolumn{2}{c}{ Tangga } \\
\cline { 2 - 3 } & Belum Diolah & Olahan \\
\hline 2015 & $1.330,30$ & $2.260,00$ \\
2016 & $1.756,60$ & $2.965,00$ \\
2017 & $2.272,80$ & $2.804,30$ \\
2018 & $2.330,60$ & $4.125,70$ \\
\hline Total & $9.245,60$ & $14.853,10$ \\
\hline
\end{tabular}

Sumber: Kementerian Perdagangan RI, diolah, 2019.

Pemerintah Indonesia mendirikan Lembaga Pengkajian Pangan, Obat-obatan dan Kosmetika Majelis Ulama Indonesia atau biasa disebut LPPOM MUI pada tahun 1989. LPPOM MUI bertugas untuk mengkaji dan menganalisa apakah suatu produk dapat dinyatakan halal baik secara mutu bahan baku 


\section{Jurnal Ilmiah Ekonomi Islam, 6(02), 2020, 295}

pembuatan, mutu proses produksi dan mutu hasil akhir produk yang akan dipasarkan pada masyarakat melalui standar yang telah diatur oleh LPPOM MUI. Namun pada kenyataanya masih banyak makanan dan minuman impor yang beredar di Indonesia yang belum memiliki sertifikart halal. Menurut laporan LPPOM MUI (LPPOM Majelis Ulama Indonesia, n.d.), produk makanan olahan halal seperti makanan ringan maupun minuman dalam kemasan yang beredar di Indonesia selama tahun 2010 sampai tahun 2015 adalah kurang dari 10\%. Diinformasikan hanya sejumlah 5\% atau sekitar 1.123 makanan ringan. Sedangkan pada produk jenis cokelat hanya $4 \%$ atau sekitar 890 produk dan pada produk olahan sebesar $4 \%$ atau sekitar 1.041 produk dari total 309.115 seluruh produk.

Tingginya nilai impor makanan dan minuman meningkatkan kekhawatiran masyarakat salah memilih produk yang dapat dikonsumsi dan mana yang tidak. Menurut MUI, pada umumnya perilaku masyarakat dalam mengonsumsi suatu produk khususnya makanan dan minuman hanya memerhatikan tanggal kedaluarsa produk tersebut dan tidak terlalu memerhatikan ada atau tidaknya label halal yang dicantumkan pada kemasan produk tersebut. Masyarakat belum paham bahwa label halal, terutama label halal yang dikeluarkan LPPOM MUI merupakan jaminan mutu, kehigienisan produk dan utamanya menjadi jaminan kehalalan produk tersebut.

Namun begitu, pengambilan keputusan untuk mengonsumsi suatu produk juga ditentukan oleh kesadaran beragama atau religiusitas dari konsumen tersebut. Menurut Rahmat dalam Astogini et al. (2011) religiusitas adalah:

"Penghayatan agama seseorang yang menyangkut simbol, keyakinan, nilai dan perilaku yang didorong oleh kekuatan spiritual. Religiusitas dapat digambarkan sebagai adanya konsistensi antara kepercayaan terhadap agama sebagai unsur kognitif, perasaan agama sebagai unsur afektif dan perilaku terhadap agama sebagai unsur psikomotorik"

Menurut Stark dan Glock, dalam Ancok \& Suroso (2011); religiusitas (religiosity) melingkupi lima dimensi yaitu, Dimensi Ritual, Ideologis, Intelektual, Pengalaman dan Konsekuensi. Menurut Ancok \& Suroso (2011) jika kelima dimensi tersebut dikaitkan dengan perspektif Islam maka dimensidimensi religiusitas Islam dapat dijelaskan sebagai berikut:
Satu, Aspek Ritual yaitu aspek yang mengukur sejauh mana seseorang melaksanakaan kewajiban ritual dari agama yang dianutnya. Dimensi ritual merupakan perilaku beragama yang berupa ibadah yang berbentuk upacara keagamaan.

Dua, aspek Ideologis; yang mengukur tingkatan sejauh mana seseorang menerima hal-hal yang bersifat dogmatis dalam agamanya. Misalnya; menerima keberadaan Tuhan, malaikat dan setan, surga dan neraka, dan lain-lain. Dalam konteks ajaran Islam, dimensi ideologis ini menyangkut kepercayaan seseorang terhadap kebenaran agamanya. Semua ajaran yang bermuara dari Al-Quran dan hadits harus menjadi pedoman bagi segala bidang kehidupan.

Tiga, dimensi Intelektual berkaitan tentang seberapa jauh seseorang mengetahui, mengerti, dan paham tentang ajaran agamanya serta sejauh mana seseorang itu mau melakukan aktivitas untuk semakin menambah pemahamannya terkait hal keagamaan yang berkaitan dengan agamanya.

Empat, dimensi Pengalaman berkaitan dengan seberapa jauh tingkat Muslim dalam merasakan dan mengalami perasan-perasaan dan pengalaman religius. Dalam Islam dimensi ini terwujud dalam perasaan dekat dengan Allah, perasaan doa-doanya sering terkabul, perasaan tentram bahagia karena menuhankan Allah dan sebagainya.

Lima, dimensi Konsekuensi berkaitan dengan sejauh mana seseorang itu mau berkomitmen dengan ajaran agamanya dalam kehidupan sehari-hari. Misalnya; menolong orang lain, bersikap jujur, mau berbagi, tidak mencuri, dan lain-lain. Berbeda dengan aspek ritual, aspek ini memfokuskan pada hubungan antar manusia menurut kerangka agama yang dianutnya.

Selain kehalalan suatu produk dan tingkat religiusitas seseorang, keputusan individu dalam mengonsumsi suatu produk juga bergantung dari kualitas produk dan ketersediaannya di pasaran. Menurut Carla Power dalam Awan et al. (2015), konsumen muslim memiliki kesamaan dengan kelompok konsumen lainnya, yaitu permintaannya terhadap makanan yang baik dan berkualitas, yang membedakan adalah selain baik dan berkualitas, konsumen muslim juga ingin makanan yang sesuai dengan syariat Islam. Selain baik dan berkualitas, konsumen juga menginginkan produk yang mudah didapat di mana pun dan kapan pun. 


\section{Jurnal Ilmiah Ekonomi Islam, 6(02), 2020, 296}

Minat individu dalam melakukan pembelian suatu produk dapat dideskripsikan dengan menggunakan Theory of Planned Behavior. Theory of Planned Behavior menjelaskan bahwa sikap individu terhadap perilaku merupakan pokok penting yang dapat memerkirakan suatu perbuatan, namun juga perlu dipertimbangkan sikap seseorang dalam menguji norma subjektif serta mengukur perceived behavioral control individu tersebut. Bila ada sikap yang positif, dukungan dari orang sekitar serta ada persepsi kemudahan untuk beperilaku maka niat seseorang untuk berperilaku akan semakin tinggi (Ajzen, 2005).

\section{Tinjauan Pustaka}

Menurut Kamus Besar Bahasa Indonesia (Kamus Besar Bahasa Indonesia, n.d.), impor adalah pemasukan barang dan sebagainya dari luar negeri. Menurut Susilo (2008) impor adalah kegiatan memasukkan barang dari suatu negara ke negara lain. Artinya kegiatan impor melibatkan dua negara atau lebih. Hal ini dapat diwakilkan oleh kepentingan perusahaan dari negara yang berbeda yang di antaranya bertindak sebagai suplier dan lainnya sebagai penerima. Produk impor dapat diartikan sebagai produk yang dibeli oleh perusahaan di suatu negara dari perusahaan yang berada di negara lain.

Perilaku konsumen, menurut Schiffman et al. (2012), adalah perilaku yang ditunjukkan individu untuk mencari, membeli, menggunakan dan mengevaluasi produk dan jasa yang diharapkan dapat memenuhi kebutuhannya. Menurut John C. \& Minor (2002), perilaku konsumen adalah studi tentang unit pembelian dan proses pertukaran yang melibatkan proses perolehan konsumsi, pembuangan barang/jasa, pengalaman serta ide-ide setelah menggunakan barang/jasa.

Islam mengajarkan umatnya untuk mengonsumsi produk yang halal dan thayyib. Dalam Islam, terdapat tiga kategori hukum yang disematkan kepada suatu produk, yaitu halal, haram dan syubhat. Halal artinya adalah diizinkan, dapat digunakan dan sah menurut hukum Islam. Sebaliknya, haram berarti tidak diizinkan sehingga dilarang untuk digunakan. Syubhat adalah hal yang masih meragukan dan dipertanyakan kedudukannya di dalam hukum Islam dan bukan termasuk kategori halal atau haram. Keputusan Menteri Agama Republik Indonesia Nomor 518 tahun 2001 tanggal 30 November 2001 pasal 1 menjelaskan bahwa pangan halal adalah pangan yang terbebas dari unsur haram yang dilarang untuk dikonsumsi umat Islam serta pengolahannya sesuai dengan yang diatur dalam syariat Islam.

Kualitas makanan halal adalah faktor terpenting bagi konsumen dalam keputusan mereka untuk membeli produk dan juga penting bagi produsen dan pemasar untuk meningkatkan kualitas produk dan meningkatkan nilai pelanggan. Newberry et al. (2003) melaporkan bahwa kualitas makanan dianggap sebagai parameter untuk memprediksi niat pembelian. Namkung \& Jang (2007) juga menunjukkan bahwa kualitas makanan memiliki pengaruh positif terhadap niat perilaku.

Sikap merupakan kecenderungan untuk menanggapi hal yang disukai dan yang tidak disukai pada suatu objek, manusia, institusi atau peristiwa (Ajzen, 1991). Sikap dianggap sebagai variabel pertama yang memengaruhi niat berperilaku seorang individu. Sikap dipengaruhi oleh keyakinan akan akibat yang terjadi dari perilaku yang dilakukan. Sikap diangap memiliki hubungan secara langsung terhadap niat dan kehendak untuk berperilaku yang kemudian dikaitkan dengan perceived behavioral control dan norma subjektif (Ajzen, 1991).

Norma subjektif merupakan suatu keyakinan individu yang dipengaruhi oleh harapan orang di sekitarnya, baik perseorangan atau kelompok, untuk melakukan suatu perilaku atau tidak melakukannya. Menurut (Suprapti, 2010), norma subjektif dapat diukur dengan menilai relevansi perseorangan atau kelompok yang menjadi panutannya, seperti keluarga, kerabat atau teman, yang akan mengharapkan atau tidak mengharapkan suatu tindakan yang dilakukannya.

Perceived behavioral control atau kontrol perilaku yang dipersepsikan adalah kemampuan untuk memperkirakan kemampuan dirinya dalam melakukan suatu perilaku. Menurut Dharmmesta (1998), perceived behavioral control adalah kondisi individu dalam meyakini suatu perilaku mudah atau sulit dilakukan, hal ini juga termasuk pengalaman terdahulu dan rintangan yang kemungkinan dapat menghalangi. Perceived behavioral control dapat berpengaruh terhadap niat berperilaku maupun secara langsung terhadap perilaku itu sendiri.

Religiusitas adalah komitmen individu kepada agamanya dan hal tersebut dicerminkan dalam sikap dan perilakunya (Ramly et al., 2008). Komitmen kepada agama membentuk dasar sikap individu dalam membuat pilihan untuk mengonsumsi sesuatu sehingga menuntun mereka ke jalan yang benar 
dalam mengambil suatu keputusan (Salman \& Siddiqui, 2011). Mengacu pada hal tersebut, agama tidak dapat ditinggalkan dalam perilaku konsumen. Agama menjadi penting karena agama membedakan mana yang boleh dan dilarang untuk dilakukan. Pada tahap pengambilan keputusan, dimulai dari tahap mencari produk yang cocok hingga tahap konsumsi produk tersebut akan bergantung pada sejauh mana komitmen seseorang dengan agamanya (Khraim, 2010).

Niat dapat diasumsikan dalam menangkap faktor-faktor motivasional yang akan berdampak pada suatu perilaku yang merupakan indikasi dari seberapa keras seseorang dalam berusaha dan seberapa banyak usaha yang akan mereka persiapkan untuk digunakan agar menampilkan perilaku. Menurut Ajzen (2005) intensi merupakan model dari sebuah perilaku yang nampak. Intensi dapat meramalkan secara akurat berbagai kecenderungan perilaku. Niat diartikan sebagai keinginan untuk melakukan suatu perilaku.

\section{Kerangka Pemikiran Teoritis Dan Perumusan Hipotesis}

\section{Hubungan Kualitas Produk Terhadap Minat Beli}

Penelitian oleh Mohtar et al. (2014) "Ayamas Food Corporation Sdn. Bhd: a Study on the Factors of Consumer Behavior Towards halal Product Selection" menunjukkan bahwa variabel yang berorientasi dengan "product" seperti kualitas produk berpengaruh secara positif terhadap keinginan konsumen memilih produk tersebut. Sejalan dengan penelitian di atas, penelitian berjudul Factors Affecting Halal Purchase Intention - Evidence from Pakistan's Halal Food Sector oleh Awan et al. (2015) mengungkapkan Halal Marketing yang salah satunya terdiri dari kualitas memengaruhi secara signifikan minat pembelian produk halal.

$\mathrm{H}_{1}$ : Kualitas produk memiliki pengaruh positif terhadap minat beli.

\section{Hubungan Sikap Terhadap Minat Beli}

Penelitian oleh Alam \& Sayuti (2011) yang berjudul "Applying the Theory of Planned Behavior (TPB) in Halal Food Purchasing" menyatakan bahwa variabel-variabel dalam Theory of Planned Behavior yaitu sikap, norma subjektif dan perceived behavioral control berpengaruh positif terhadap minat membeli produk makanan halal. Temuan ini sejalan dengan hasil penelitian oleh Haque et al. (2018) yang berjudul Muslim Consumers' Purchase Behavior Towards Halal Cosmetic Products in Malaysia menyatakan bahwa sikap, norma subjektif dan perceived behavioral control memiliki pengaruh signifikan terhadap minat beli produk kosmetik di Malaysia

$\mathrm{H}_{2}$ : Sikap memiliki pengaruh positif terhadap minat beli.

\section{Hubungan Norma Subjektif Terhadap Minat Beli}

Penelitian oleh Rachbini (2018) yang berjudul "The Relationship of Attitude, Subjective Norm, Perceived Behavioral Control on Halal Food Purchasing Behavior in Jakarta" menyatakan bahwa sikap, norma subjektif dan perceived behavioral control berpengaruh secara positif terhadap minat beli. temuan ini sejalan dengan hasil penelitian oleh Khalek (2014) yang berjudul "Young consumers' attitude towards halal food outlets and JAKIM's halal certification in Malaysia" yang menyatakan bahwa norma subjektif memiliki hubungan yang positif terhadap minat beli.

$\mathrm{H}_{3}$ : Norma Subjektif memiliki pengaruh positif terhadap minat beli.

\section{Hubungan Perceived Behavioral Control Terhadap Minat Beli}

Penelitian oleh Armitage \& Conner (2001) yang berjudul "Efficacy of The Theory of Planned Behavior: A Meta-Analytic Review" menyatakan bahwa terdapat hubungan yang positf antara perceived behavioral control dengan minat beli. Temuan ini sejalan dengan hasil penelitian oleh Khalek \& Ismail (2015) yang menyatakan bahwa sikap, norma subjektif dan perceived behavioral control berpengaruh secara positif terhadap minat beli.

$\mathrm{H}_{4}$ : Perceived behavioral control memiliki pengaruh positif terhadap minat beli.

\section{Hubungan Religiusitas Terhadap Minat Beli}

Religiusitas merupakan salah satu aspek budaya terpenting yang memengaruhi perilaku konsumen. Selain itu agama juga memiliki peran penting seperti dalam mengonsumsi makanan bagi seorang Muslim di Negara Islam ataupun Negara yang bukan Islam. Penelitian yang dilakukan oleh Mukhtar \& Butt (2012) menunjukkan bahwa religiusitas berpengaruh positif terhadap minat beli. Selain itu penelitian yang dilakukan oleh Rois (2016) menunjukkan bahwa 
religiusitas juga memiliki pengaruh terhadap minat beli.

$\mathrm{H}_{5}$ : Religiusitas memiliki pengaruh positif terhadap minat beli.

Berdasarkan penjabaran hubungan variabel independen dan variabel dependen di atas, maka dapat disimpulkan kerangka pemikiran seperti pada Gambar 1 berikut:

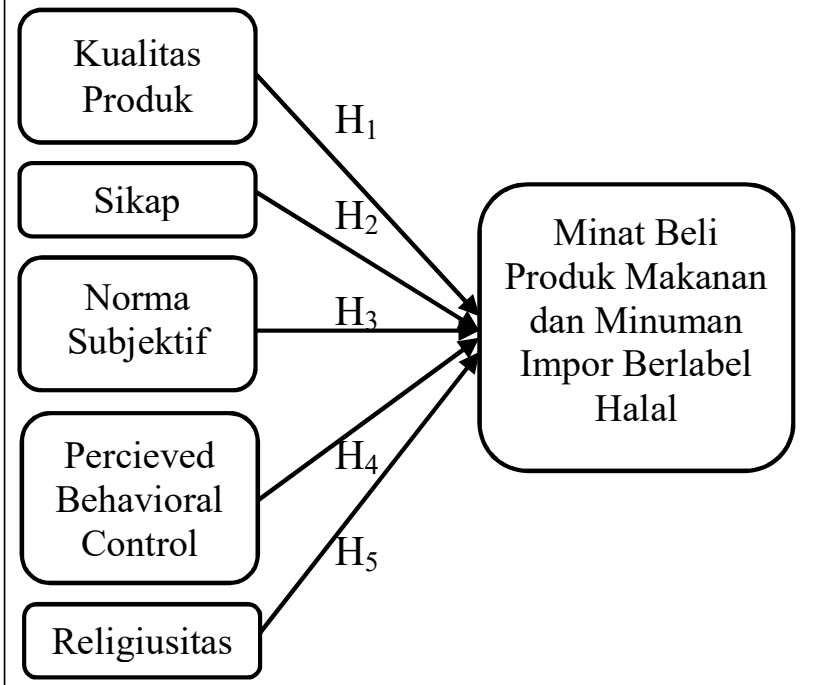

Gambar 1 Kerangka Pemikiran Penelitian

Adapun Hipotesis pada penelitian ini adalah sebagai berikut:

$\mathrm{H}_{1}$ : Kualitas produk memiliki pengaruh positif terhadap minat beli makanan dan minuman impor berlabel halal pada mahasiswa Universitas Diponegoro Semarang.

$\mathrm{H}_{2}$ : Sikap memiliki pengaruh positif terhadap minat beli makanan dan minuman impor berlabel halal pada mahasiswa Universitas Diponegoro Semarang.

$\mathrm{H}_{3}$ : Norma subjektif memiliki pengaruh positif terhadap minat beli makanan dan minuman impor berlabel halal pada mahasiswa Universitas Diponegoro Semarang.

$\mathrm{H}_{4}$ : Perceived behavioral control memiliki pengaruh positif terhadap minat beli makanan dan minuman impor berlabel halal pada mahasiswa Universitas Diponegoro Semarang.

$\mathrm{H}_{5}$ : Religiusitas memiliki pengaruh positif terhadap minat beli makanan dan minuman impor berlabel halal pada mahasiswa Universitas Diponegoro Semarang.

\section{METODE PENELITIAN}

Variabel dependen (terikat) merupakan variabel yang terpengaruh atau yang menjadi akibat karena adanya variabel independen (bebas) (Sugiyono, 2014). Variabel dependen dalam penelitian ini adalah tingkat minat beli mahasiswa muslim Universitas Diponegoro terhadap makanan dan minuman impor berlabel halal. Variabel independen (bebas) merupakan variabel yang memengaruhi atau yang menjadi sebab perubahan atau timbulnya variabel dependen (Sugiyono, 2014). Variabel independen dalam penelitian ini adalah kualitas produk, sikap, norma subjektif, perceived behavioral control, dan religiusitas.

Populasi pada penelitian ini adalah seluruh mahasiswa Universitas Diponegoro yang berjumlah 47.918 mahasiswa. Jumlah sampel penelitian ini mengacu pada metode penentuan jumlah minimal sampel dengan metode Slovin dalam Sugiyono (2014) dengan rumus pada Persamaan 1 berikut:

Persamaan (1)

$$
\begin{aligned}
& \mathrm{n}=\frac{\mathrm{N}}{1+\mathrm{N}^{2}} \\
& \mathrm{n}=\text { jumlah sampel } \\
& \mathrm{N}=\text { populasi } \\
& \alpha=\text { toleransi ketidaktelitian: } 10 \% \text { atau } 0.1
\end{aligned}
$$

Berdasarkan data yang diperoleh dari pangkalan data pendidikan tinggi (Kementerian Riset Teknologi dan Pendidikan Tinggi, n.d.), diketahui bahwa jumlah populasi mahasiswa Universitas Diponegoro adalah sebanyak 47.918 mahasiswa. Berdasarkan Persamaan 1, jumlah sampel yang dibutuhkan penelitian ini adalah:

$$
\begin{aligned}
& \mathrm{n}=\frac{\mathrm{N}}{1+\mathrm{N}^{2}}=\frac{47.918}{1+47.918(0,1)^{2}}=99,791 \text { dibulatkan } \\
& \text { menjadi } 100 \text { orang. }
\end{aligned}
$$

Berdasarkan Persamaan 1 di atas, maka sampel yang dibutuhkan pada penelitian ini sebanyak 100 orang, namun penulis menggunakan sampel yang lebih besar yaitu sebanyak 110 orang.

Metode pengambilan sampel yang digunakan dalam penelitian ini adalah metode purposive sampling dengan 3 kategori sebagai berikut, pertama, merupakan mahasiswa aktif; kedua, beragama Islam; ketiga, mengonsumsi makanan dan minuman impor berlabel halal minimal 1x dalam 2 minggu terakhir.

Teknik penentuan sampel pada penelitian ini adalah berdasarkan kebetulan melalui kuesioner online Google Form, artinya siapa saja yang sesuai 


\section{Jurnal Ilmiah Ekonomi Islam, 6(02), 2020, 299}

kriteria yang ditentukan peneliti dapat menjadi responden dan mengisi kuesioner Google Form melalui tautan yang dibagikan.

Pengujian hasil kuesioner atau angket dengan menggunakan analisis validitas dan reliabilitas. Sedangkan pengujian atau analisis data penelitian menggunakan uji asumsi klasik dan analisis regresi berganda yaitu uji simultan (F), uji parsial (t), uji $R^{2}$.

\section{HASIL DAN PEMBAHASAN}

\section{a. Hasil Penelitian}

\section{Analisis Regresi Linear Berganda}

Berdasarkan jenis kelamin, sebaran responden dapat dilihat pada Tabel 2 berikut:

Tabel 2 Responden Berdasarkan Jenis Kelamin

\begin{tabular}{lcc}
\hline Jenis Kelamin & Jumlah (orang) & Persentase (\%) \\
\hline Laki-laki & 46 & 41,82 \\
Perempuan & 64 & 58,18 \\
\hline Jumlah & 110 & 100 \\
\hline
\end{tabular}

Berdasarkan Tabel 2 di atas dapat dilihat bahwa responden mayoritas berjenis kelamin perempuan dengan jumlah 64 orang atau $58,18 \%$ dari total 110 responden. Hal ini mungkin disebabkan oleh kenyataan bahwa mahasiswa Universitas Diponegoro berjenis kelamin perempuan lebih banyak daripada laki-laki.

Tabel 3 Hasil Analisis Regresi Linear Berganda

\begin{tabular}{|c|c|c|c|c|c|c|}
\hline & & Unstandardized & Coefficients & $\begin{array}{l}\text { Standardized } \\
\text { Coefficients }\end{array}$ & & \\
\hline & Model & B & Std. Error & Beta & $t$ & Sig. \\
\hline$\overline{1}$ & (Constant) & -18.879 & 9.325 & & -2.024 & .045 \\
\hline & total_KP & .424 & .213 & .154 & 1.988 & .049 \\
\hline & total_S & .186 & .074 & .233 & 2.525 & .013 \\
\hline & total_NS & .051 & .065 & .076 & .789 & .432 \\
\hline & total_PBC & .277 & .083 & .290 & 3.330 & .001 \\
\hline & total_R & 1.353 & .311 & .319 & 4.357 & .000 \\
\hline
\end{tabular}

$\mathrm{Y}=\alpha+\beta 1 \mathrm{X} 1+\beta 2 \mathrm{X} 2+\beta 3 \mathrm{X} 3+\beta 4 \mathrm{X} 4+\beta 5 \mathrm{X} 5+\mathrm{e}$

Dari hasil analisis regresi pada Tabel 3 dapat diketahui persamaan regresi linier berganda sebagai berikut:

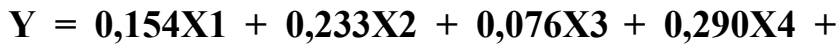
$0,319 \times 5+\mathrm{e}$

Hal tersebut bermakna:

Pertama, koefisien faktor kualitas produk $\left(\mathrm{X}_{1}\right)$ bernilai 0,154 , yang berarti bahwa jika faktor kualitas produk meningkat, maka tingkat minat beli produk makanan dan minuman impor berlabel halal akan meningkat, dengan asumsi variabel lain tetap (tidak berubah).
Kedua, koefisien faktor sikap $\left(\mathrm{X}_{2}\right)$ bernilai 0,233 , yang berarti bahwa jika faktor sikap meningkat, maka tingkat minat beli produk makanan dan minuman impor berlabel halal akan meningkat, dengan asumsi variabel lain tetap (tidak berubah).

Ketiga, koefisien faktor norma subjektif $\left(\mathrm{X}_{3}\right)$ bernilai 0,076 , yang berarti bahwa jika faktor norma subjektif meningkat, maka tingkat minat beli produk makanan dan minuman impor berlabel halal akan meningkat, dengan asumsi variabel lain tetap (tidak berubah).

Keempat, koefisien faktor perceived behavioral control $\left(\mathrm{X}_{4}\right)$ bernilai 0,290 , yang berarti bahwa jika faktor perceived behavioral control meningkat, maka tingkat minat beli produk makanan dan minuman impor berlabel halal akan meningkat, dengan asumsi variabel lain tetap (tidak berubah).

Kelima, koefisien faktor religiusitas $\left(\mathrm{X}_{5}\right)$ bernilai 0,319 , yang berarti bahwa jika faktor perceived behavioral control meningkat, maka tingkat minat beli produk makanan dan minuman impor berlabel halal akan meningkat, dengan asumsi variabel lain tetap (tidak berubah).

Uji $\boldsymbol{F}$

\begin{tabular}{|c|c|c|c|c|c|}
\hline \multicolumn{5}{|c|}{ ANOVA $^{\mathrm{a}}$} & \\
\hline Model & Sum of Squares & df & Mean Square & $\mathrm{F}$ & Sig. \\
\hline 1 Regression & 1634.333 & 5 & 326.867 & 18.526 & $.000^{\circ}$ \\
\hline Residual & 1834.985 & 104 & 17.644 & & \\
\hline Total & 3469.318 & 109 & & & \\
\hline
\end{tabular}

a. Dependent Variable: total_NB

b. Predictors: (Constant), total_R, total_KP, total_S, total_PBC, total_NS

Hasil pada uji $\mathrm{F}$ secara simultan diperoleh nilai signifikasi 0.000 (perhatikan Tabel 4) yang lebih kecil dari 0,05 dan nilai $\mathrm{F}$ hitung 18,526 (perhatikan Tabel 4) yang lebih besar dari nilai $F$ Tabel 2,30 sehingga dapat disimpulkan variabel independen yaitu kualitas produk, sikap, norma subjektif, perceived behavioral control dan religiusitas berpengaruh positif dan signifikan secara simultan terhadap minat beli. 


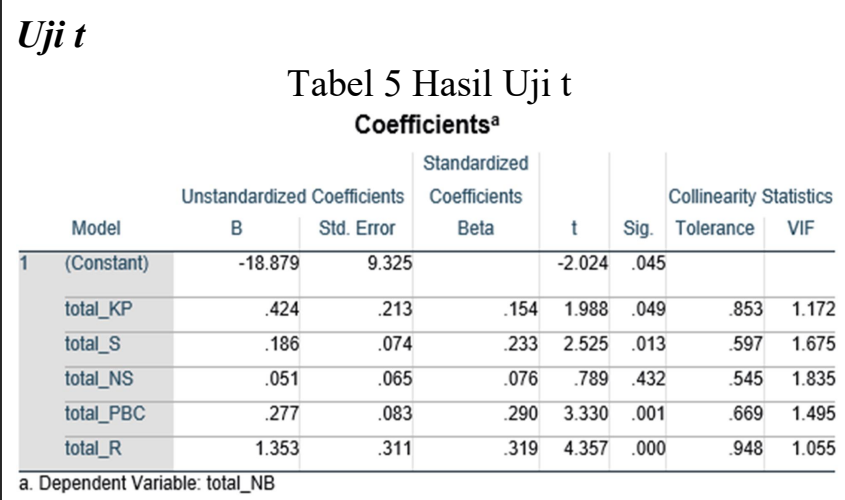

Penjelasan hasil uji $\mathrm{t}$ untuk masing-masing variabel bebas adalah sebagai berikut:

\section{Kualitas Produk}

Kualitas produk memiliki nilai signifikansi sebesar 0,049 dan nilai $\mathrm{t}$ hitung 1,988. Nilai signifikansi 0,049 lebih kecil dari 0,05 dan nilai $\mathrm{t}$ hitung 1,988 lebih besar dari 1,65936 sehingga dapat disimpulkan variabel kualitas produk berpengaruh signifikan secara parsial terhadap variabel minat beli.

\section{Sikap}

Sikap memiliki nilai signifikansi sebesar 0,013 dan nilai thitung 2,525. Nilai signifikansi 0,013 lebih kecil dari 0,05 dan nilai t hitung 2,525 lebih besar dari 1,65936 sehingga dapat disimpulkan variabel sikap berpengaruh secara parsial terhadap variabel minat beli.

\section{Norma Subjektif}

Norma Subjektif memiliki nilai signifikansi sebesar 0,432 dan nilai $t$ hitung 0,789. Nilai signifikansi 0,432 lebih besar dari 0,05 dan nilai $t$ hitung 0,789 lebih besar dari 1,65936 sehingga dapat disimpulkan variabel norma subjektif tidak berpengaruh secara parsial terhadap variabel minat beli.

\section{Perceived Behavioral Control}

Perceived behavioral control memiliki nilai signifikansi sebesar 0,001 dan nilai t hitung 3,330. Nilai signifikansi 0,001 lebih kecil dari 0,05 dan nilai t hitung 3,276 lebih besar dari 1,65936 sehingga dapat disimpulkan variabel perceived behavioral control berpengaruh positf dan signifikan secara parsial terhadap variabel minat beli.

\section{Religiusitas}

Religiusitas memiliki nilai signifikansi sebesar 0,000 dan nilai $\mathrm{t}$ hitung 4,357. Nilai signifikansi
0,000 lebih kecil dari 0,05 dan nilai t hitung 4,357 lebih besar dari 1,65936 sehingga dapat disimpulkan variabel religiusitas berpengaruh positif dan signifikan secara parsial terhadap variabel minat beli. Uji $\boldsymbol{R}^{2}$

\begin{tabular}{c|r|r|r|r|}
\multicolumn{9}{c}{$\begin{array}{c}\text { Tabel 6 Hasil Uji R } \\
\text { Model Summary }\end{array}$} \\
Model & $\mathrm{R}$ & R Square & $\begin{array}{c}\text { Adjusted R } \\
\text { Square }\end{array}$ & $\begin{array}{c}\text { Std. Error of the } \\
\text { Estimate }\end{array}$ \\
\hline 1 & $.686^{\mathrm{a}}$ & .471 & .446 & 4.200 \\
\hline
\end{tabular}

a. Predictors: (Constant), total_R, total_KP, total_S, total_PBC, total_NS b. Dependent Variable: total_NB

Berdasarkan Tabel 6, hasil uji koefisien determinasi menghasilkan nilai $\mathrm{R}^{2}$ sebesar 0,471 . Hal ini dapat diartikan koefisien determinasi $\left(\mathrm{R}^{2}\right)$ sebesar 0,471, artinya variasi variabel kualitas produk, sikap, norma subjektif, perceived behavioral control dan religiusitas memengaruhi sebanyak $47,1 \%$ terhadap variabel minat beli mahasiswa Undip terhadap produk makanan dan minuman impor berlabel halal. Sedangkan 52,9\% dipengaruhi variabel independen yang tidak terdapat pada penelitian ini.

\section{b. Pembahasan}

Pengaruh Kualitas Produk terhadap Minat Beli Mahasiswa Universitas Diponegoro pada Produk Makanan dan Minuman Impor Berlabel Halal

Berdasarkan hasil uji regresi linear berganda, disimpulkan bahwa variabel kualitas produk memiliki pengaruh signifikan secara parsial terhadap variabel minat beli. Hal ini didasarkan pada hasil uji t bahwa nilai signifikansi 0,049 (perhatikan Tabel 5) lebih kecil dari 0,05 dan nilai t hitung 1,988 (perhatikan Tabel 5) lebih besar dari 1,65936 sehingga dapat disimpulkan variabel kualitas produk berpengaruh sginifikan secara parsial terhadap variabel minat beli. Berdasarkan hasil tersebut maka hipotesis kualitas produk memiliki pengaruh positif dan signifikan terhadap minat beli makanan dan minuman impor berlabel halal pada mahasiswa Universitas Diponegoro Semarang $\left(\mathrm{H}_{1}\right)$ diterima. Menurut interpretasi penulis, hal ini dikarenakan kualitas merupakan hal krusial bagi konsumen untuk menentukan apakah suatu produk layak untuk dibeli dan dibeli secara berulang.

Hasil ini berbanding lurus dengan hasil penelitian terdahulu (Awan et al., 2015; Mohtar et al., 2014) yang menyatakan bahwa kualitas produk secara parsial berpengaruh postif dan signifikan terhadap minat beli. 
Pengaruh Sikap terhadap Minat Beli Mahasiswa Universitas Diponegoro pada Produk Makanan dan Minuman Impor Berlabel Halal

Berdasarkan hasil uji regresi linear berganda, disimpulkan bahwa variabel sikap memiliki pengaruh signifikan secara parsial terhadap variabel minat beli. Hal ini didasarkan pada hasil uji $t$ bahwa nilai signifikansi 0,013 (perhatikan Tabel 5) lebih kecil dari 0,05 dan nilai t hitung 2,525 (perhatikan Tabel 5) lebih besar dari 1,65936 sehingga dapat disimpulkan variabel sikap berpengaruh signifikan secara parsial terhadap variabel minat beli. Berdasarkan hasil tersebut maka hipotesis sikap memiliki pengaruh positif terhadap minat beli makanan dan minuman impor berlabel halal pada mahasiswa Universitas Diponegoro Semarang $\left(\mathrm{H}_{2}\right)$ diterima. Menurut interpretasi penulis, hal ini dikarenakan sikap terhadap produk berlabel halal menjadi salah satu alas an bagi konsumen untuk memilih produk berlabel halal.

Hasil ini berbanding lurus dengan hasil penelitian terdahulu (Alam \& Sayuti, 2011; Haque et al., 2018; Khalek, 2014; Rachbini, 2018) yang menyatakan bahwa sikap secara parsial berpengaruh postif dan signifikan terhadap minat beli.

\section{Pengaruh Norma Subjektif terhadap Minat Beli Mahasiswa Universitas Diponegoro pada Produk Makanan dan Minuman Impor Berlabel Halal}

Berdasarkan hasil uji regresi linear berganda, disimpulkan bahwa variabel sikap tidak memiliki pengaruh secara parsial terhadap variabel minat beli. Hal ini didasarkan pada hasil uji t bahwa nilai signifikansi 0,432 (perhatikan Tabel 5) lebih besar dari 0,05 dan nilai t hitung 0,789 (perhatikan Tabel 5) lebih kecil dari 1,65936 sehingga dapat disimpulkan variabel sikap tidak berpengaruh secara parsial terhadap variabel minat beli. Berdasarkan hasil tersebut maka hipotesis norma subjektif memiliki pengaruh positif terhadap minat beli makanan dan minuman impor berlabel halal pada mahasiswa Universitas Diponegoro Semarang $\left(\mathrm{H}_{3}\right)$ ditolak. Menurut interpretasi penulis, hal ini disebabkan oleh sikap yang positif dan signifikan terhadap minat beli produk makanan dan minuman impor berlabel halal sehingga dorongan eksternal tidak signifikan terhadap individu responden.

Hasil ini sejalan dengan hasil penelitian terdahulu (Haque et al., 2018) yang menyatakan bahwa norma subjektif tidak berpengaruh postif terhadap minat beli. Namun hasil ini berbanding terbalik dengan hasil sebagian penelitian terdahulu (Alam \& Sayuti, 2011; Khalek, 2014; Rachbini, 2018) yang menyatakan bahwa norma subjektif secara parsial berpengaruh postif terhadap minat beli.

Pengaruh Perceived Behavioral Control terhadap Minat Beli Mahasiswa Universitas Diponegoro pada Produk Makanan dan Minuman Impor Berlabel Halal

Berdasarkan hasil uji regresi linear berganda, disimpulkan bahwa variabel perceived behavioral control memiliki pengaruh secara parsial terhadap variabel minat beli. Hal ini didasarkan pada hasil uji t bahwa Nilai signifikansi 0,001 (perhatikan Tabel 5) lebih kecil dari 0,05 dan nilai $\mathrm{t}$ hitung 3,330 (perhatikan Tabel 5) lebih besar dari 1,65936 sehingga dapat disimpulkan variabel sikap berpengaruh secara parsial terhadap variabel minat beli. Berdasarkan hasil tersebut maka hipotesis perceived behavioral control memiliki pengaruh positif terhadap minat beli makanan dan minuman impor berlabel halal pada mahasiswa Universitas Diponegoro Semarang $\left(\mathrm{H}_{4}\right)$ diterima. Menurut interpretasi penulis, hal ini disebabkan oleh perasaan penting untuk mengikuti arahan atau saran dari orang terdekat.

Hasil ini sejalan dengan hasil penelitian terdahulu (Alam \& Sayuti, 2011; Haque et al., 2018; Khalek, 2014; Rachbini, 2018) yang menyatakan bahwa perceived behavioral control secara parsial berpengaruh positif terhadap minat beli.

Pengaruh Religiusitas terhadap Minat Beli Mahasiswa Universitas Diponegoro pada Produk Makanan dan Minuman Impor Berlabel Halal

Berdasarkan hasil uji regresi linear berganda, disimpulkan bahwa variabel religiusitas memiliki pengaruh secara parsial terhadap variabel minat beli. Hal ini didasarkan pada hasil uji $t$ bahwa Nilai signifikansi 0,000 (perhatikan Tabel 5) lebih kecil dari 0,05 dan nilai t hitung 4,357 (perhatikan Tabel 5) lebih besar dari 1,65936 sehingga dapat disimpulkan variabel sikap berpengaruh secara parsial terhadap variabel minat beli. Berdasarkan hasil tersebut maka hipotesis religiusitas memiliki pengaruh positif terhadap minat beli makanan dan minuman impor berlabel halal pada mahasiswa Universitas Diponegoro Semarang $\left(\mathrm{H}_{5}\right)$ diterima. Menurut interpretasi penulis, hal ini disebabkan karena keimanan atau religiusitas merupakan pondasi seorang muslim dalam menentukan pilihan dalam bersikap dan berlaku. 
Hasil ini sejalan dengan hasil penelitian terdahulu (Awan et al., 2015) yang menyatakan bahwa religiusitas secara parsial berpengaruh positif terhadap minat beli. Selain itu, variabel kualitas produk, sikap, norma subjektif, perceived behavioral control dan religiusitas juga berpengaruh secara simultan atau bersama-sama terhadap variabel minat beli. Hal ini didasarkan pada hasil uji $\mathrm{F}$ bahwa secara simultan diperoleh nilai signifikasi 0.000 (perhatikan Tabel 6) yang lebih kecil dari 0,05 dan nilai F hitung 18,526 (perhatikan Tabel 6) yang lebih besar dari nilai $F$ Tabel 2,30.

\section{KESIMPULAN}

Berdasarkan hasil pembahasan dari penelitian ini, kesimpulan dari penelitian adalah sebagai berikut: pertama, berdasarkan hasil uji analisis linear berganda, 4 dari 5 variabel independen, secara parsial, berpengaruh positif dan signifikan terhadap minat beli mahasiswa muslim di Universitas Diponegoro pada produk makanan dan minuman impor berlabel halal. Variabel tersebut adalah variabel kualitas produk, sikap, perceived behavioral control, dan religiusitas. Variabel yang tidak signifikan adalah variabel norma subjektif. Menurut intepretasi penulis, hal ini disebabkan oleh sikap yang positif dan signifikan terhadap minat beli produk makanan dan minuman impor berlabel halal sehingga dorongan eksternal tidak signifikan terhadap individu responden. Kedua, variabel kualitas produk, sikap, norma subjektif, perceived behavioral control dan religiusitas berpengaruh secara simultan terhadap minat beli mahasiswa Universitas Diponegoro pada produk makanan dan minuman impor berlabel halal.

\section{UCAPAN TERIMA KASIH}

Terimakasih kami ucapkan kepada Ketua Program Studi Ekonomi Islam Fakultas Ekonomika dan Bisnis Universitas Diponegoro, Darwanto, S.E., M.Si., M.Sy yang telah memfasilitasi proses publikasi artikel penelitian ini.

\section{REFERENSI}

Ajzen, I. (1991). The Theory of Planned Behavior. Organizational Behavior and Human Decision Processes, 50, 179-211. https://doi.org/10.4135/9781446249215.n22

Ajzen, I. (2005). Attitude, Personality, and Behavior (2nd ed.). University Press.
Alam, S. S., \& Sayuti, N. M. (2011). Applying the Theory of Planned Behavior (TPB) in halal food purchasing. International Journal of Commerce and Management, 21(1), 8-20. https://doi.org/10.1108/10569211111111676

Ancok, D., \& Suroso, F. N. (2011). Psikologi Islami Solusi Islam Atas Problem-Problem Psikologi. Pustaka Pelajar.

Armitage, C. J., \& Conner, M. (2001). < Armitage and Connor 2001.Pdf>. British Journal of Social Psychology, 40, 471. https://pdfs.semanticscholar.org/ab83/87ae29317 c651a129efc7a2297bc5f348a95.pdf

Astogini, D., Wahyudin, \& Wulandari, S. Z. (2011). Aspek Religiusitas dalam Keputusan Pembelian Produk Halal. Jeba, 13(1), 1-8.

Awan, H. M., Siddiquei, A. N., \& Haider, Z. (2015). Factors affecting Halal purchase intention evidence from Pakistan's Halal food sector. Management Research Review, 38(6), 640-660. https://doi.org/10.1108/mrr-01-2014-0022

Badan Pusat Statistik. (2010). Sensus Penduduk Indonesia

2010.

https://sp2010.bps.go.id/index.php/site/tabel?tid $=321 \&$ wid $=0$

Haque, A., Anwar, N., Tarofder, A. K., Ahmad, N. S., \& Sharif, S. R. (2018). Muslim consumers' purchase behavior towards halal cosmetic products in Malaysia. Management Science Letters, $\quad$ 8(12), 1305-1318. https://doi.org/10.5267/j.ms1.2018.9.009

John C., M., \& Minor, M. (2002). Perilaku Konsumen (L. Salim (ed.); 1st ed.). Erlangga.

Kamus Besar Bahasa Indonesia. (n.d.). KBBI Daring Kemdikbud. Retrieved September 29, 2019, from https://kbbi.kemdikbud.go.id

Kementerian Riset Teknologi dan Pendidikan Tinggi. (n.d.). Profil Perguruan Tinggi. https://forlap.ristekdikti.go.id/perguruantinggi/de tail/NTREMDFCRjMtODI1NS00NzRCLUI5Nk QtNDQyNjEzNUVFRDAx

Khalek, A. A. (2014). Young Consumers' Attitude towards Halal Food Outlets and JAKIM's Halal Certification in Malaysia. Procedia - Social and Behavioral Sciences, 121(September 2012), 2634.

https://doi.org/10.1016/j.sbspro.2014.01.1105 


\section{Jurnal Ilmiah Ekonomi Islam, 6(02), 2020, 303}

Khalek, A. A., \& Ismail, S. H. S. (2015). Why Are We Eating Halal - Using the Theory of Planned Behavior in Predicting Halal Food Consumption among Generation Y in Malaysia. International Journal of Social Science and Humanity, 5(7), 608-612.

https://doi.org/10.7763/ijssh.2015.v5.526

Khraim, H. (2010). Measuring Religiosity in Consumer Research from Islamic Perspective. International Journal of Marketing Studies, 2(2), 166-179. https://doi.org/10.5539/ijms.v2n2p166

LPPOM Majelis Ulama Indonesia. (n.d.). Data Sertifikasi Halal LPPOM MUI Periode 20112018.

https://www.halalmui.org/muil4/main/page/data -sertifikasi-halal-lppom-mui-periode-20112018

Mohtar, N. M., Amirnordin, N. A., \& Haron, H. (2014). Ayamas Food Corporation Sdn. Bhd: A Study on the Factors of Consumer Behaviour towards Halal Product Selection. Procedia Social and Behavioral Sciences, 121(September 2012), 166-185. https://doi.org/10.1016/j.sbspro.2014.01.1118

Mukhtar, A., \& Butt, M. M. (2012). Intention to choose Halal products: The role of religiosity. Journal of Islamic Marketing, 3(2), 108-120. https://doi.org/10.1108/17590831211232519

Namkung, Y., \& Jang, S. (2007). Does Food Quality Really Matter in Restaurants? Its Impact On Customer Satisfaction and Behavioral Intentions. Journal of Hospitality \& Tourism Research: The Professional Journal of the Council on Hotel, Restaurant, and Institutional Education, 31(3), 387-409.

https://doi.org/10.1177/1096348007299924
Newberry, C. R., Klemz, B. R., \& Boshoff, C. (2003). Managerial Implications of Predicting Purchase Behavior arom Purchase Intentions: A Retail Patronage Case Study. The Journal of Services Marketing, 17(6), 609-619. https://doi.org/10.1108/08876040310495636

Rachbini, W. (2018). The Relationship of Attitude , Subjective Norm, Perceived Behavioral Control on Halal Food Purchasing Behavior in Jakarta. IOSR Journal of Business and Management (IOSR-JBM) e-ISSN: 2278-487X, p-ISSN: 23197668. 20(1), 28-37. https://doi.org/10.9790/487X-2001082837

Ramly, Z., Chai, L. T., \& Lung, C. K. (2008). Religiosity as a Predictor of Consumer Ethical Behaviour: Some Evidence from Young Consumers from Malaysia. Journal of Business Systems, Governance and Ethics, 3(4), 43-56. https://doi.org/10.15209/jbsge.v3i4.147

Salman, F., \& Siddiqui, K. (2011). An exploratory study for measuring consumers awareness and perceptions towards halal food in Pakistan. Interdisciplinary Journal of Contemporary Research in Business, 3(2), 639-651.

Schiffman, L. G., Kanuk, L. L., \& Hansen, H. (2012). Consumer Behavior: a Eruopean Outlook (2nd ed.). Pearson Education Limited.

Sugiyono. (2014). Metode Penilitian Bisnis. Alfabeta. Suprapti, N. W. S. (2010). Perilaku Konsumen, Pemahaman Dasar dan Aplikasinya dalam Strategi Pemasaran. Udayana University Press.

Susilo, A. (2008). Buku Pintar Ekspor-Impor: Manajemen Tata Laksana dan Transportasi Internasional (1st ed.). TransMedia. 